\title{
GENETIC PARAMETERS FOR SOME MILK PRODUCTION TRAITS OF HOLSTEIN COWS IN A COMMERCIAL HERD IN EGYPT
}

\author{
S. Abou-Bakr, N. Hamdy, A.F.I. El-Kholy, M.A.M. Ibrahim, R.R. Sadek \\ and A.A. Nigm \\ Department of Animal Production, Faculty of Agriculture, University of Cairo, \\ Giza, Egypt
}

\section{SUMMARY}

A total number of 1923 complete record for 1167 Holstein cows sired by 59 sires were used to estimate heritability and genetic and phenotypic correlations for milk production traits. Records covered the period from 1992 to 2002. The studied traits were 305 day milk yield (305-dMY), initial milk yield (milk yield from calving to peak, IMY), daily peak milk yield (PMY), time to attain daily peak milk (TTP), and persistency of lactation. Data were analyzed using DF-REML procedure (Meyer, 1998).

Estimates of heritability for 305-dMY, IMY, PMY and TTP were 0.141, 0.004, 0.190 and 0.001 , respectively. Estimates of heritability for persistency measures ranged from 0.009 to 0.064 .

Genetic and phenotypic correlations obtained between 305 day milk yield and all other studied traits were positive except for correlations with some persistency measures which were negative.

The results of this study suggest that an early selection for 305 day milk yield can be practiced using peak milk yield ( $r_{g}=0.98$ and $\left.h^{2}=0.19\right)$.

Keywords: Genetic parameters, milk production, persistency, Holstein, commercial herd, Egypt

\section{INTRODUCTION}

The major factors affecting milk yield and lactation curve are initial milk yield, peak milk yield and the persistency of lactation (Gupta and Johar, 1982). Initial milk yield is a reliable indicator of the genetic potentials and could be used as a measure for an early selection (Sharma and Bhatnagar, 1973).

Peak milk yield was described by Roy and Katpatal (1988) as an indicator to the maximum level of physiological activity which measures the inherent capability of the animal. As peak yield expresses the milk production potential, and since it has high association with lactation yield, it can be also used as an early measure for selection or culling (Rekik et al., 2003).

Persistency of lactation is a desirable trait because it affects and determines the total milk yield (Haile-Mariam et al., 2003). Genetic improvement for persistency

Issued by The Egyptian Society of Animal Production 
can be used to increase the average level of persistency in the herd through selection (Dekkers et al., 1998).

The objective of the present study was to estimate genetic parameters (heritability and genetic correlation) of some dairy traits (305-day milk yield, initial milk yield, peak milk yield, time to attain peak and persistency of lactation) of Holstein cows maintained at a commercial herd in Egypt.

\section{MATERIALS AND METHODS}

A total number of 1923 complete lactation record was edited from 23511 test day records for 1167 Holstein cows daughters of 59 sires and 480 dams. Calvings occurred during the period from 1992 to 2002, at El-Tobgy farm at Fayoum 80 kilometers south of Cairo. Animals were kept under open sheds and divided in groups according to their milk production and pregnancy status. Total mixed ration (TMR) was used in feeding animals. Cows were machine milked three times daily. Artificial insemination by Holstein frozen semen imported from U.S.A and Canada was practiced. Cooling system was used to help heat dissipation during the summer and spring months. The studied herd is enrolled in the milk recording system operated by Cattle Information System/Egypt (CISE) of Cairo University.

The studied traits are: $305-\mathrm{dMY}(\mathrm{kg}): 305$ day milk yield [(TMY*405)/(LP+100)], where, LP is lactation period and TMY is total milk yield, (ICAR,2000),DMY (kg): $\operatorname{IMY}(\mathrm{kg})$ : initial milk yield to peak, PMY $(\mathrm{kg})$ : daily peak milk yield (the maximum daily milk yield), TTP(day): time to attain daily peak milk yield. Persistency of lactation was calculated by five methods as follows:

P1= coefficient of variation (C.V) for test day yields, (Rao and Sundaresan, 1979);

$\mathrm{P} 2=$ (maximum daily milk yield/mean of all test day yield) $* 100$, (Leukkunen, 1985);

$\mathrm{P} 3, \% \mathrm{P}=2 *[\mathrm{~S}(\mathrm{x}>\mathrm{X})-\mathrm{n} \mathrm{X}] * 100 / \mathrm{Sx},(\mathrm{McD}$ owell et al., 1961). Where,

$\% \mathrm{P}$ is persistency in percentage, expressed as the rate of decline of milk yield,

$\mathrm{S}(\mathrm{x}>\mathrm{X})$ is sum of yields for 30 day periods, greater than the average 30 day yield for the lactation,

$\mathrm{n}$ is number of periods when 30-day yield exceeded the average for the lactation, and

$\mathrm{Sx}$ is sum of all 30day yields.

P4 = 305-dMY/maximum daily milk yield, (Rao and Sundaresan, 1982)

$\mathrm{P} 5=$ (the second five test days / the first five test days)*100, (Leukkunen, 1985)

Higher values of P1, P2 and P3 mean lower persistency and vice versa.

Heritability and genetic correlation $\left(r_{g}\right)$ and phenotypic correlation $\left(r_{p}\right)$ were estimated using Derivative-Free Restricted Maximum Likelihood (DF-REML) procedure (Meyer, 1998). The model used was as follow:

$\mathrm{Y}_{\mathrm{ijklm}}=\mu+\mathrm{a}_{\mathrm{i}}+\mathrm{pe}_{\mathrm{i}}+\mathrm{P}_{\mathrm{j}}+\mathrm{S}_{\mathrm{k}}+\mathrm{R}_{\mathrm{l}}+\mathrm{b}\left(\mathrm{X}_{\mathrm{ijklm}} \overline{\mathrm{X}}\right)+\mathrm{e}_{\mathrm{ijklm}}$

Where,

$\mu=$ the overall mean,

$\mathrm{a}_{\mathrm{I}}=$ additive genetic random effect of the individual $\mathrm{i}$,

$\mathrm{pe}_{\mathrm{i}}=$ permanent environmental random effect on individual 1 ,

$\mathrm{P}_{\mathrm{j}}=$ the fixed effect of parity $\mathrm{j}(\mathrm{j}=$ five levels $)$, 
$\mathrm{S}_{\mathrm{k}}=$ the fixed effect of $\mathrm{k}^{\text {th }}$ season of calving $(\mathrm{k}=1,2,3$ and 4$)$, where $1=$ winter (December-February); 2= Spring (March- May); 3= Summer (JuneAugust) and 4= Autumn (September- November),

$R_{1}=$ the fixed effect of $1^{\text {th }}$ year of calving $1(1=1,2, \ldots, 11)$

$\mathrm{b}=$ the linear regression coefficient of the studied traits on age at calving,

$X_{\mathrm{ijklm}}=$ the age at calving,

$\overline{\mathrm{X}}=$ the average age at calving, and

$\mathrm{e}_{\mathrm{ijk} l \mathrm{~m}}=$ the error term assumed $\left(0, \sigma_{\mathrm{e}}^{2}\right)$.

\section{RESULTS AND DISCUSSION}

Means and standard errors of 305-dMY $(\mathrm{kg}), \operatorname{IMY}(\mathrm{kg}), \operatorname{PMY}(\mathrm{kg})$, and TTP(day) are presented in table (1). Estimates obtained in the present study lie within the range of estimates reported for Holsteins in the Egyptian literature (Nigm et al., 2003; Nigm et al., 2006 and Salem et al., 2006). Heritability estimates for the studied milk production traits are shown in table (2). Heritability of 305-dMY (0.14) is comparable with estimate of 0.13 obtained by some of the Egyptian authors (AbouBakr et al., 2000 and Kassab, 2001).

Table 1. Means and standard errors (SE) of milk production traits of Holstein cows

\begin{tabular}{lcc}
\hline \multicolumn{1}{c}{ Trait } & Mean & SE \\
\hline 305-dMY, kg & 7396 & 21 \\
IMY, kg & 2380 & 34 \\
PMY, kg & 32 & 0.13 \\
TTP, day & 105 & 1.5 \\
P1 & $27 \%$ & 0.20 \\
P2 & 140 & 0.42 \\
P3 & $22 \%$ & 0.17 \\
P4 & 225 & 0.57 \\
P5 & $84 \%$ & 0.40 \\
\hline
\end{tabular}

Table 2. Estimates of heritability $\left(h^{2}\right)$ and standard errors (SE) for milk production traits of Holstein cows

\begin{tabular}{lcc}
\hline \multicolumn{1}{c}{ Trait } & $\mathbf{h}^{2}$ & SE \\
\hline 305-dMY, kg & 0.141 & 0.080 \\
IMY, kg & 0.004 & 0.065 \\
PMY, kg & 0.190 & 0.085 \\
TTP, day & 0.001 & 0.075 \\
P1 & 0.062 & 0.060 \\
P2 & 0.009 & 0.045 \\
P3 & 0.064 & 0.053 \\
P4 & 0.033 & 0.040 \\
P5 & 0.014 & 0.062 \\
\hline
\end{tabular}

A great influence of environmental factors on IMY and TTP is obvious where they have a small values of heritability ( 0.004 and 0.001 , respectively). 
Heritability estimate of PMY is 0.190 , the same value recorded by El-Arian and Shalaby (2001) during their study on the first lactation of Friesian cattle raised in Egypt.

Estimates of heritability of persistency differed according to the method used in calculation. All values are low and ranged from 0.009 to 0.064 . This range is lower than those reported by foreign studies but it is similar to values recorded in studies conducted in Egypt on Friesian cattle (0.025 by Abubakr, 1991 and 0.057 and 0.074 by El-Arian and Shalaby, 2001).

Positive genetic and phenotypic correlations (table 3) were obtained between 305 day milk yield and each of the other traits, except for the negative correlation with P1, P2 and P3. A high correlation was obtained between 305 milk yield and PMY $\left(r_{\mathrm{g}}=0.98\right.$, and $\mathrm{r}_{\mathrm{p}}=0.82$, respectively). Although selection for peak yield will not improve lactation yield per generation to the extend expected from selection for lactation yield, it may reduce generation interval. Further, it will be more convenient to record the peak yield than the lactation yield.

Genetic and phenotypic estimates of persistency with 305-dMY differed according to the method used in calculation. P1, P2 and P3 showed negative correlation while P4 and P5 showed positive correlation with all the studied traits, except for their phenotypic correlation with PMY. It took a different trend where MY correlated with P1, P2 and P3 positively, and negatively with P4 and P5.

Table 3. Estimates of genetic correlation ( $r_{g}$, above diagonal) and phenotypic correlation ( $r_{p}$, below diagonal) among milk production traits

\begin{tabular}{lccccccccc}
\hline Trait & 305 -dmy & PMY & IMY & TTP & P1 & P2 & P3 & P4 & P5 \\
\hline 305-dMY & & 0.980 & 0.009 & 0.006 & -0.670 & -0.130 & -0.639 & 0.440 & 0.370 \\
PMY & 0.820 & & -0.140 & -0.080 & -0.318 & -0.850 & -0.447 & 0.089 & 0.047 \\
IMY & 0.003 & -0.070 & & 0.350 & -0.020 & -0.053 & -0.023 & 0.160 & 0.300 \\
TTP & 0.002 & -0.049 & 0.040 & & -0.530 & -0.560 & -0.890 & 0.090 & 0.090 \\
P1 & -0.126 & 0.238 & -0.001 & -0.030 & & 0.468 & 0.988 & -0.990 & -0.800 \\
P2 & -0.038 & 0.280 & -0.023 & -0.110 & 0.168 & & 0.750 & -0.140 & -0.150 \\
P3 & -0.135 & 0.263 & -0.001 & -0.180 & 0.970 & 0.189 & & -0.966 & -0.920 \\
P4 & 0.246 & -0.302 & 0.062 & 0.083 & -0.714 & -0.014 & -0.760 & & 0.980 \\
P5 & 0.134 & -0.280 & 0.060 & 0.084 & -0.162 & -0.015 & -0.118 & 0.320 & \\
\hline
\end{tabular}

\section{CONCLUSION}

Selecting dairy cows for 305-dMY using their PMY would be more effective when compared with that depending on persistency of lactation.

Effective improvement of persistency should depend mainly on improving environmental and management conditions.

The ratio between 305-day milk yield and the maximum daily milk yield (P4) seemed to be a good measure for persistency of lactation. It has strong positive correlation with 305-day milk yield, besides it is easy to calculate.

\section{REFERENCES}

Abou-bakr, S., U.M. El-Saied and M.A.M. Ibrahim, 2000. Genetic and phenotypic paramters for milk yield, days open and number of services per conception of Holstein cows of a commercial herd in Egypt. Egypt. J. Anim. Prod., 37(1):9-17.

Abubakr, H.A. 1991. A genetic study on the lactation curve in Friesian cattle. M. Sc. Thesis, Fac. Agric., Ain Shams Univ. Egypt.

Dekkers, J.C., J.H. TenHag and A. Werrsink, 1998. Economic aspects of Persistency of lactation in dairy cattle. Livest. Prod. Sci., 53:237-252. 
El-Arian, M.N. and N.A. Shalaby, 2001. Genetic analysis for lactation curve traits and persistency indices for Friesian cattle in Egypt. J. Agric. Sci., Mansoura Univ., 26:1957-1973.

Gupta, R.N. and K.S. Johar, 1982. Genetic and non-genetic factors Affecting persistency of first lactation in Tharparkar. 35:99 (CAB Abstr.).

Haile-Mariam, M., P.J. Bowman and M.E. Goddard, 2003. Genetic and Environmental relationship among calving interval, survival, Persistency of milk yield and somatic cell count in dairy cattle. Livest. Prod. Sci., 80:189-200.

ICAR, 2000. Yearly enquiry on the situation and results of cow milk recording in member countries. International Committee for Animal Recording. Paris, France.

Kassab, M.S., 2001. Relationship between days open and milk production in a commercial herd of Holstein Friesian cows in Egypt. J. Agric. Res. Tanta Univ., 27:210-218.

Leukkunen, A., 1985. Parameters for persistency of milk yield in the Finnish Ayrshire cattle. Tierzuchtg Zuchtgsbiol.,102:117.

McDowell, R.E., J.C. Johnson, J.L. Fletcher and W.R. Harvey, 1961. Production characteristics of Jersey and Red-Sindhi-Jersey crossbred females. J. Dairy Sci., 44:125-140.

Meyer, K., 1998. Derivative-Free Restricted Maximum Likelihood (DF-REML) package. Version 3.1, $6^{\text {th }}$ world cong. Genetic Appl. Livest. Prod. Armidal, New Southwales, Australi.

Nigm, A.A., S. Abou-Bakr, K. Abdel-Rahman, R.R. Sadek and M.A.Morsy, 2006. Dairy performance characteristics of Holstein and its crosses with European Friesian in a large commercial herd in Egypt. J. Agric. Sci. Mansoura Univ., 31:3407.

Nigm, A.A., A.A. Attallah, S. Abou-Bakr and R.R. Sadek, 2003. A study on applying test day model for genetic evaluation of milk yield of Holstein cattle in Egypt. Egypt. J. Anim. Prod., 40:89-98.

Rao, M.K. and D. Sundaresan, 1979. Influence of environment and heredity on the shape of lactation curves in Sahiwal cows. J. Agri. Sci., Cambridge, 92:393-401.

Rao, M.K., and D. Sundaresan, 1982. Factors affecting the shape of lactation curve in Friesian X Sahiwal crossbred cows. Indian J. Dairy,35:160-167.

Rekik, B., A.B. Gara, M.B. Hamouda and H.Hammami, 2003. Fitting lactation curves of dairy cattle in different types of herd in Tunisia. Livest. Prod. Sci., 83:309-315.

Roy, T.C. and B.G. Katpatal, 1988. Genetic studies on first lactation peak Yield and days to attain peak yield in Jersey cattle. Indian Vet. J., 65:1103-1108.

Salem, M.A., H.M. Esmail, R.R. Sadek and A.A.Nigm, 2006. Phenotypic and genetic parameters of milk production and reproductive performance of Holstein cattle under the intensive production system in Egypt. Egypt. J. Anim. Prod.,43:1-10.

Sharma, R.C. and D.S. Bhatnagar, 1973. Persistency of milk production in the first lactation in dairy cattle, its heritability estimate and its relationship with production traits. Indian Vet. J.,50:530-535. 
المعايير الوراثية لبعض صفات إنتاج اللبن لأبقار الهولثتين فى قطيع تجارى فى مصر

سامى أبو بكر، ناديـة حمدى فهيم، أحمد فريد الخولى، محد عبد العزيز إبراهيم، ربيع رجب

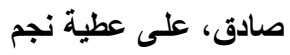

قسم الإنتاج الحيواتس، كلية النزاعة، جامعة القاهزة، الجبيزة، مصر

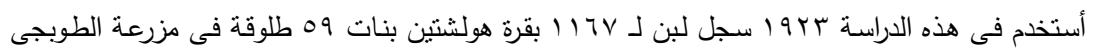

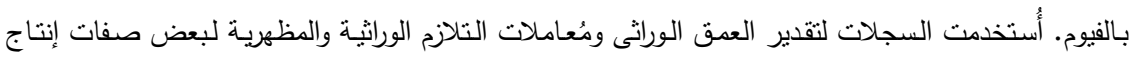

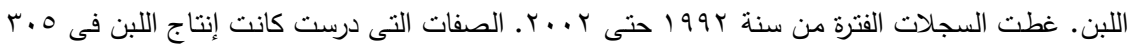

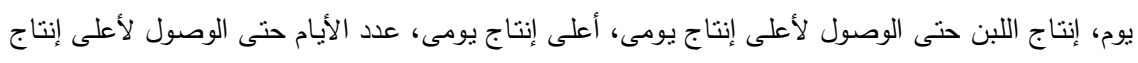

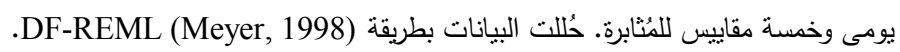

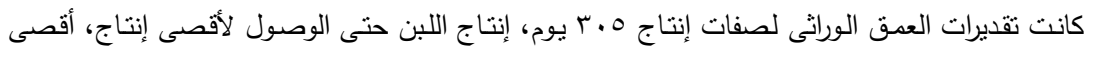

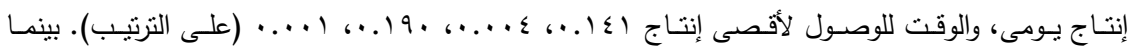

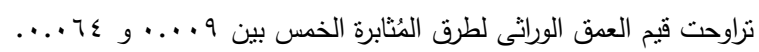

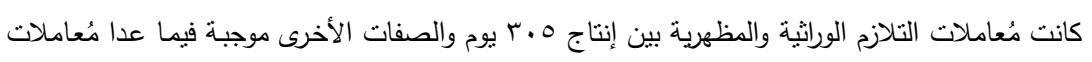

التلازم مع تقديرات المُئابرة فكانت جميعها سالتخة.

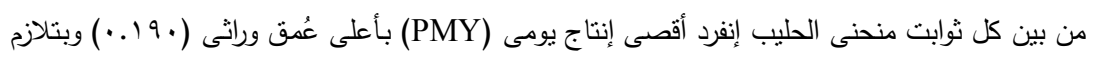

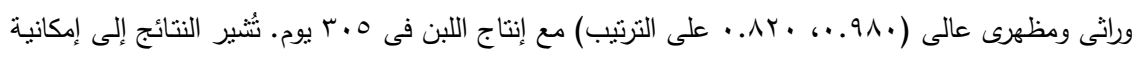

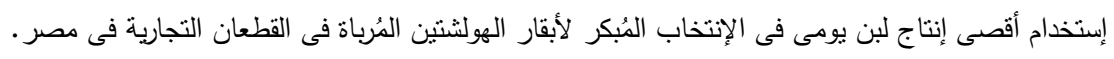

